medRxiv preprint doi: https://doi.org/10.1101/2020.05.14.20098608; this version posted May 19, 2020. The copyright holder for this preprint (which was not certified by peer review) is the author/funder, who has granted medRxiv a license to display the preprint in perpetuity.

It is made available under a CC-BY-NC-ND 4.0 International license .

Alétheia research group

${ }^{1}$ Physiotherapist. Cardiopulmonary

Rehabilitation Specialist, Magister of Health Sciences, Magister of Palliative Care. Comprehensive Rehabilitation Center S.C. in the Hospital Ángeles Lomas Huixquilucan, México. Jepr87@hotmai.com

${ }^{2}$ Physiotherapist. IPS Diversity Foundation. Medellín, Colombia. Juankmilo_30@hotmail.com

${ }^{3}$ Physiotherapist. Comprehensive Rehabilitation Center S.C. in the Hospital Ángeles Lomas Huixquilucan, México. Otiliolopez555@gmail.com

${ }^{4}$ Physiotherapist. Organization Management and Leadership Teacher. Director of Physiotherapy and Rehabilitation of Comprehensive Rehabilitation Center S.C. in the Hospital Ángeles Lomas Huixquilucan, México. Sharonwaiss@yahoo.com

${ }^{5}$ Physiotherapist. Especialista en Fisioterapia Cardiopulmonar. Clínica San José. Cúcuta, Colombia.Ximavela@yahoo.com

The authors declare that they have no conflict of interest.

\section{VENTILATORY SUPPORT IN SARS-VOC-2 DURING INTENSIVE THERAPY}

\author{
Pereira-Rodríguez Javier Eliecer ${ }^{1}$, Quintero-Gomez Juan Camilo², Lopez-
}

Florez Otilio ${ }^{3}$, Waiss-Skvirsky Sandra Sharon ${ }^{4}$, Velásquez-Badillo Ximena ${ }^{5}$.

\section{ABSTRACT}

Introduction: The SARS-CoV-2 disease outbreak has now become a pandemic. Critical patients with COVID-19 require basic and advanced respiratory support. Therefore, the objective was to describe the ventilatory support strategies in SARS-CoV-2 during intensive therapy.

Materials and methods: A systematic review of observational studies of the available scientific literature was performed in accordance with the recommendations of the Cochrane collaboration and the criteria of the PRISMA Declaration.

Results: Fifteen observational studies were included that gave a study population of 4,081 patients. Mechanical ventilation is the main respiratory support treatment for critically ill patients, which should be administered as soon as normal oxygenation cannot be maintained, and despite the fact that there is no current consensus on the parameters of mechanical ventilation, the evidence collected suggests the use of Fio2 on average 50\%, PEEP of 14 cmH2O, lung compliance of $29-37 \mathrm{ml}$ per $\mathrm{cm}$ of water, driving pressure between $12-14 \mathrm{~cm}$ of water and a plateau pressure of $22-25 \mathrm{~cm}$ of water.

Conclusions: IL- 6 is shown as a possible marker of respiratory failure and a worse prognosis as well as obesity. In addition, the use of prone position, neuromuscular blockade, pulmonary vasodilators, ECMO, and mechanical ventilation based on the clinical conditions and needs of the patient with COVID-19 are strategies that could benefit patients entering intensive therapy for SARS-CoV- 2.

Key words: COVID-19, SARS-CoV-2, mechanical ventilation. 
medRxiv preprint doi: https://doi.org/10.1101/2020.05.14.20098608; this version posted May 19, 2020. The copyright holder for this preprint (which was not certified by peer review) is the author/funder, who has granted medRxiv a license to display the preprint in perpetuity.

It is made available under a CC-BY-NC-ND 4.0 International license .

\section{RESUMEN}

Introducción: El brote de enfermedad por SARS-CoV-2 actualmente se ha convertido en una pandemia. Pacientes críticos con COVID-19 requieren soporte respiratorio básico y avanzado. Por lo tanto, el objetivo fue describir las estrategias de soporte ventilatorio en SARS-CoV-2 durante terapia intensiva.

Materiales y métodos: Se realizó una revisión sistemática de estudios observacionales de la literatura científica disponible de acuerdo con las recomendaciones de la colaboración Cochrane y los criterios de la Declaración PRISMA.

Resultados: Se incluyeron 15 estudios observacionales que otorgaron una población de estudio de 4.081 pacientes. La ventilación mecánica es el principal tratamiento de apoyo respiratorio para pacientes críticos, que debe administrarse tan pronto como no se pueda mantener la oxigenación normal y a pesar de que no existe un consenso actual sobre los parámetros de ventilación mecánica, la evidencia recolectada sugiere el uso de Fio2 en promedio del 50\%, PEEP de $14 \mathrm{cmH} 2 \mathrm{O}$, compliance pulmonar de 29-37 ml por $\mathrm{cm}$ de agua, driving pressure entre $12-14 \mathrm{~cm}$ de agua y una presión plateau de $22-25 \mathrm{~cm}$ de agua.

Conclusiones: La IL-6 se muestra como un posible marcador de falla respiratoria y peor pronostico al igual, que la obesidad. Además, el uso de posición prona, bloqueo neuromuscular, vasodilatadores pulmonares, ECMO y una ventilación mecanica basada en las condiciones clínicas y necesidades del paciente con COVID-19 son estrategias que podrían beneficar a los pacientes que ingresan a terapia intensiva por SARS-CoV-2.

Palabras clave: COVID-19, SARS-CoV-2, ventilación mecanica. 
medRxiv preprint doi: https://doi.org/10.1101/2020.05.14.20098608; this version posted May 19, 2020. The copyright holder for this preprint (which was not certified by peer review) is the author/funder, who has granted medRxiv a license to display the preprint in perpetuity. It is made available under a CC-BY-NC-ND 4.0 International license .

\section{INTRODUCCIÓN}

SARS-CoV-2 is a coronavirus infection disease recently discovered in humans, which comes from the Coronavirus family and is affecting the world population, becoming a matter of public calamity.

The outbreak of Coronavirus disease was first reported in Wuhan, China on December 31, 2019, and has now become a pandemic, affecting the world population. According to the last report of the World Health Organization (WHO) ${ }^{1}$ for March 30, 2020. 215 territories had reported confirmed cases of COVID-19), 1'655.378 in the Region of the Americas (98.723 deaths), 1'707.946 in the European Region (155.552 deaths), 255.728 in the Eastern Mediterranean Region (8.878 deaths), 159.662 cases in the Eastern Pacific Region (6.470 deaths), 95.314 in the Southeast Asia Region (3.356 deaths), 42.626 in the African Region (1.369 deaths).

According to the European Center for Disease Prevention and Control, as of May 10, 2020, there were almost 4 million (3'986.119) cases of COVID-19 and 278.814 deaths worldwide. Some of the countries with the highest number of deaths for the same date were: United States (78.794), United Kingdom (31.587), Italy (30.395), Spain (26.478), France (26.310), Brazil (10.627), among others. Likewise, an ECDPC analysis with 17 countries in Europe determined that the most commonly reported clinical symptoms were fever $(47 \%)$, dry or productive cough $(25 \%)$, sore throat $(16 \%)$, general weakness $(6 \%)$ and pain $(5 \%)$; hospitalization occurred in $30 \%(13.122$ of 43.438) of the cases reported in 17 countries, and the cases requiring ICU or respiratory support represented 2.179 of $49.282(4 \%)^{2}$.

Understanding that there is still no clarity on the treatment for patients with Coronavirus, it has been described based on the pathophysiology of COVID-19 requiring advanced life support needs, ranging from oxygen supplementation through non-invasive ventilation, to invasive mechanical ventilation and vasopressor support; some secondary complications described in confirmed cases include cardiomyopathy, pulmonary embolism, and sudden death ${ }^{3,4}$.

Based on the available data, it is defined that the viral infection is capable of producing an excessive immune reaction in the host, generating in turn what is called "cytokine storm", an effect of extensive tissue damage in cascade; Interleukin 6 (IL-6) is the main proinflammatory protein produced by leukocytes in cases of COVID-19, and which act on a large number of cells and tissues. In this way, and unlike other types of Coronavirus described above, SARS-CoV-2 has 
medRxiv preprint doi: https://doi.org/10.1101/2020.05.14.20098608; this version posted May 19, 2020. The copyright holder for this preprint (which was not certified by peer review) is the author/funder, who has granted medRxiv a license to display the preprint in perpetuity. It is made available under a CC-BY-NC-ND 4.0 International license .

shown greater systemic involvement than others, mainly of respiratory origin associated with pneumonia $^{5,6}$.

In one of the first reports on the disease, chest computed tomography (CT) was performed on patients with COVID-19, where pneumonia with abnormal findings was evident in all cases. About a third of them (13.32\%) required intensive care unit (ICU) care, and there were $6(15 \%)$ fatal cases. From this, the needs for assistance and support in the ICUs of all the countries of the world has increased. Likewise, each time the cases of acute respiratory distress syndrome (ARDS) and SARS-CoV-2-associated pneumonia continue to grow, which has forced the assistance of mechanical ventilation in these $\operatorname{cases}^{7,8,9}$.

A report by the Intensive Care National Audit and Research Center (ICNARC) ${ }^{10}$ in the United Kingdom described the results of an observational cohort study with 165 patients in critical care units. Of the 165 patients, 79 (47.9\%) died and 86 (52.1\%) were discharged alive from the ICU. On the other hand, $58.8 \%$ of the patients required advanced respiratory support, $50.3 \%$ basic respiratory support, $20.6 \%$ advanced cardiovascular support, $84.2 \%$ basic cardiovascular support, $17 \%$ renal support and $2.4 \%$ required neurological support.

The percentage of patients with SARS-CoV-2 who require advanced ventilatory support, such as mechanical ventilation (MV), is high. However, there are currently no specific protocols for the management of MV in these patients. On the other hand, the need for updating based on scientific evidence on the assistance and management of mechanical ventilation in patients with SARS-CoV2 has increased. Thus, this study aims to describe the ventilatory support strategies in SARS-CoV2 during intensive therapy.

\section{MATERIALS AND METHODS}

\section{$\underline{\text { Design }}$}

A systematic review was performed with a descriptive analysis of retrospective chronology of clinical trials, case reports, systematic reviews and meta-analyzes, available and published in indexed databases. Research that included experimental studies with human beings had informed consent under the ethical considerations of Helsinki ${ }^{11}$, for the regulation of experimental studies in living beings. 
medRxiv preprint doi: https://doi.org/10.1101/2020.05.14.20098608; this version posted May 19, 2020. The copyright holder for this preprint (which was not certified by peer review) is the author/funder, who has granted medRxiv a license to display the preprint in perpetuity. It is made available under a CC-BY-NC-ND 4.0 International license .

\section{Search strategy}

The search for scientific documents was developed under the considerations and criteria of the PRISMA Flow Chart ${ }^{12}$ (Transparent Reporting Items for Systematic Reviews and Meta-Analyzes) for the identification, screening, eligibility and inclusion of studies in systematic reviews.

Different databases were reviewed for the identification of prospective documents based on the criteria of the PRISMA Diagram for text search. These search criteria are defined as: records identified through the database search, additional records identified through other sources, records after duplicates have been removed, selected records, full-text articles evaluated for eligibility, and finally studies included in qualitative synthesis. The databases identified for searching scientific studies included: PubMed and PubMed Central.

\section{Boolean descriptors and operators}

Descriptors associated with the variables described in the study title were used: mechanical ventilation \& COVID-19; and the boolean operators: AND \& OR. Thus, the search strategy was as follows: ("respiration, artificial" [MeSH Terms] OR ("respiration" AND "artificial") OR "artificial respiration" OR ("mechanical" AND "ventilation") OR "mechanical ventilation" [) AND ("COVID-19" OR "COVID-2019" OR "severe acute respiratory syndrome coronavirus 2" OR "severe acute respiratory syndrome coronavirus 2" OR "2019-nCoV" OR "SARS-CoV-2" OR "2019nCoV "OR (((" Wuhan "AND (" coronavirus "[MeSH Terms] OR" coronavirus ")) AND (2019/12 OR 2020))).

\section{Selection of studies}

The selection of articles was made by the different authors of the study. At first, one author (JCQG) identified prospective studies, later a second author (OL-P) carried out the screening or screening process, a third researcher (SSW-S) applied eligibility criteria, and finally full text analysis and included by previous collaborators. To reduce study selection and inclusion bias, each of the research collaborators independently reviewed the studies chosen to analyze the full text using the PRISMA Checklist ${ }^{13}$, to finally agree on the studies to include in the sample (n). On the other hand, a fourth researcher. 
medRxiv preprint doi: https://doi.org/10.1101/2020.05.14.20098608; this version posted May 19, 2020. The copyright holder for this preprint (which was not certified by peer review) is the author/funder, who has granted medRxiv a license to display the preprint in perpetuity.

It is made available under a CC-BY-NC-ND 4.0 International license .

\section{Selection criteria}

Eligibility criteria were defined in the PRISMA Checklist, according to the design characteristics of the included studies and characteristics of the reported population. Among the general criteria applied to all the studies, the place of publication, year of publication, type of literature, language of publication, study design, methodology, nature and characteristics of the population were taken into account.

From the above, studies published in indexed databases, documents available to date, scientific article-type texts, experimental and descriptive design research on the application and management of mechanical ventilation in humans with coronavirus acquired in the current pandemic. Some data such as sex, age, anthropometric characteristics, ethnicity and comorbidities were not filtered; one author (JEPR) verified that the ethical recommendations were complied with in each of the included investigations; all the collaborators verified the application of inclusion criteria.

\section{Data collection and extraction}

The data were extracted into a selection matrix for the identified, screened, chosen and finally included studies, designed by the authors through "Excel" spreadsheets. Data from the studies chosen in the systematic review were collected on information analysis sheets. The information on the studies included in the review was described using characterization tables on text sheets.

\section{Type of participants}

Subjects of both genders, from any region of the world with confirmed diagnosis for COVID-19, who received supplemental oxygen from invasive or non-invasive mechanical ventilation were included.

\section{RESULTS}

\section{Selection of studies and characteristics}

After the initial search, 1,128 titles were identified regarding the use of mechanical ventilation in patients with COVID-19. A total of 104 documents were selected that described cases of patients who required mechanical ventilation due to the severe hypoxemia generated by the coronavirus. Subsequently, 64 studies were chosen for full-text review (study objective, interventions carried out, results obtained and conclusions). 
medRxiv preprint doi: https://doi.org/10.1101/2020.05.14.20098608; this version posted May 19, 2020. The copyright holder for this preprint (which was not certified by peer review) is the author/funder, who has granted medRxiv a license to display the preprint in perpetuity.

It is made available under a CC-BY-NC-ND 4.0 International license .

Finally, 15 observational studies were included ${ }^{15-29}$ (figure 1) after the full text review, on mechanical ventilation in COVID-19 that were published between February 9, 2020 and April 15, 2020; 3 clinical cohort studies ${ }^{20,26,27}$ and 12 retrospective clinical studies ${ }^{15-19,21-25,28,29}$. In this way, the sample size (n) of each included study, the main diagnosis, the information collection methodology, the time, results and conclusions of each study included in the systematic review were determined (table 1).
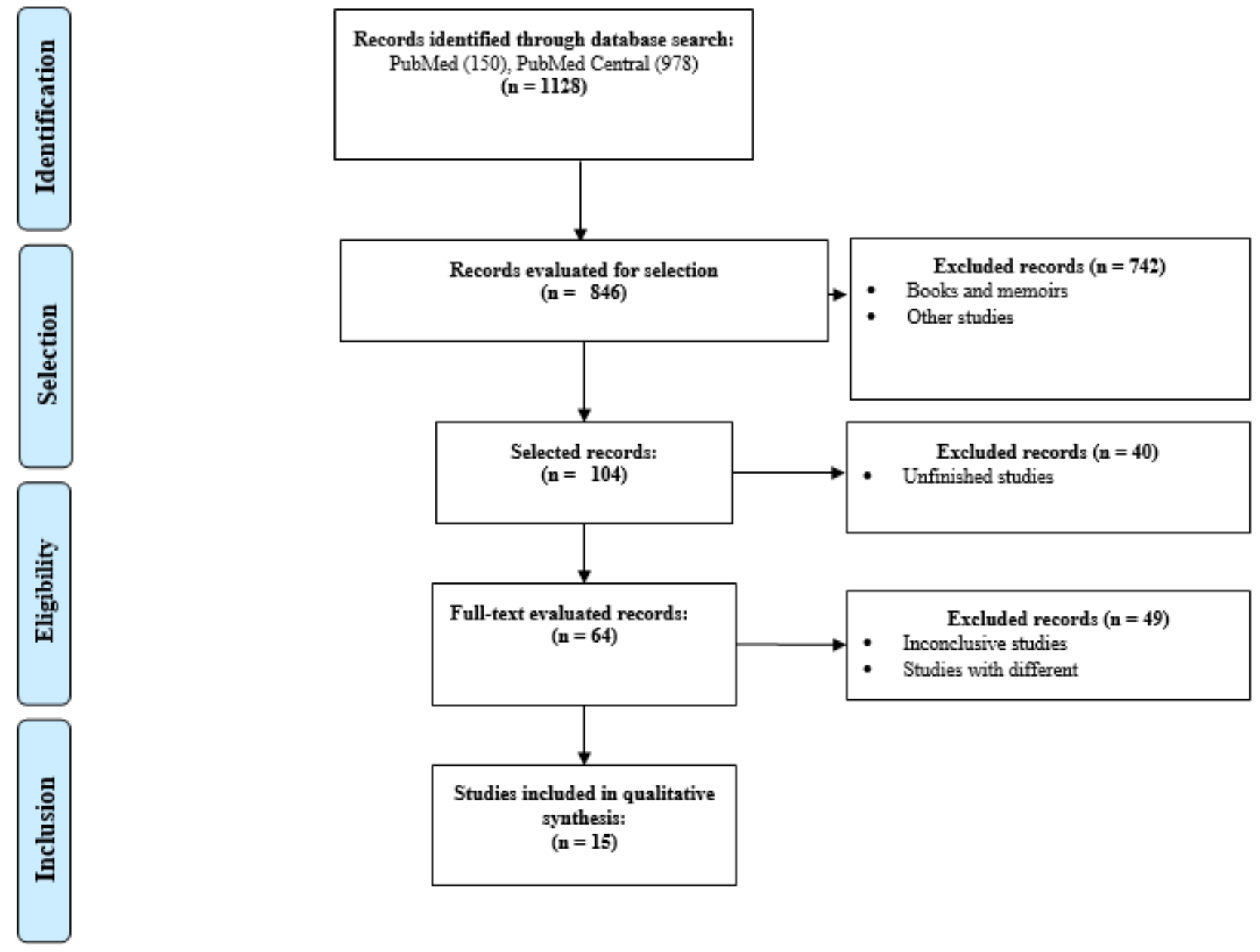

Fig. 1. Illustration of the PRISMA Flowchart for the Identification, selection, eligibility and inclusion of studies in systematic reviews. 
Table 2. Characteristics of the interventions of the included studies $(n=15)$

\begin{tabular}{|c|c|c|c|c|c|c|c|}
\hline Author & $n$ & $\begin{array}{l}\text { Type of } \\
\text { study }\end{array}$ & Population & Methodology & Duration & Results & Conclusions \\
\hline $\begin{array}{ll}\text { Barrasa } & H, \\
\text { et al. } & \end{array}$ & 48 & $\begin{array}{l}\text { Retrospective } \\
\text { clinical case } \\
\text { study }\end{array}$ & $\begin{array}{l}\text { P patients } \\
\text { with COVID-19 }\end{array}$ & $\begin{array}{l}\text { I was you identify } \\
\text { with rum patients from } \\
\text { two public hospitals in } \\
\text { Vitoria admitted to the } \\
\text { ICU with confirmed } \\
\text { infection by SARS-CoV- } \\
\text { 2. The data reported here } \\
\text { was available on March } \\
31,2020 \text {. Mortality was } \\
\text { assessed in those who } \\
\text { completed } 7 \text { days of ICU } \\
\text { stay. }\end{array}$ & - & $\begin{array}{l}\text { All patients were admitted for } \\
\text { hypoxemic respiratory failure } \\
\text { and none received non-invasive } \\
\text { mechanical ventilation. Forty- } \\
\text { five }(94 \%) \text { underwent } \\
\text { intubation, } 3 \text { t nasal high-flow } \\
\text { oxygen therapy, } 1 \text { (2\%) } \\
\text { extracorporeal membrane } \\
\text { oxygenation (ECMO), and } 22 \\
(49 \%) \text { required a prone } \\
\text { position. After } 15 \text { days, } 14 / 45 \\
(31 \%) \text { intubated patients died } \\
(13 \% \text { in one week), } 10 \text { (22\%) } \\
\text { were extubated, and } 21 / 45 \\
(47 \%) \text { underwent mechanical } \\
\text { ventilation. Six patients had } \\
\text { documented coinfection. }\end{array}$ & $\begin{array}{l}\text { A correct oxygenation strategy to avoid } \\
\text { non-invasive mechanical ventilation saves } \\
\text { lives . Seven-day mortality in SARS-CoV-2 } \\
\text { requiring intubation was less than } 15 \% \text {, and } \\
80 \% \text { of patients still required mechanical } \\
\text { ventilation. After } 15 \text { days of ICU admission, } \\
\text { half of the patients remained intubated, } \\
\text { while a third died. }\end{array}$ \\
\hline $\begin{array}{l}* \text { Chen J, et } \\
\text { al. }{ }^{17}\end{array}$ & 101 & $\begin{array}{l}\text { Retrospective } \\
\text { clinical case } \\
\text { study }\end{array}$ & $\begin{array}{l}\mathrm{P} \text { deceased patients with COVID- } \\
19\end{array}$ & $\begin{array}{l}\mathrm{R} \text { is eclut aron all cases } \\
\text { of death COVID-19 on } \\
\text { December 30, } 2019 \text { on } \\
\text { February 16,2020 in the } \\
\text { intensive care unit of the } \\
\text { Hospital Wuhan } \\
\text { Jinyintan. Demographics, } \\
\text { basic } \\
\text { diseases, X- ray and CT }\end{array}$ & 6 weeks & $\begin{array}{l}\text { All patients received antibiotic } \\
\text { treatment, } 63 \quad(62.38 \%) \text { used } \\
\text { restricted antibiotics, } 23 \\
(22.78 \%) \text { used antifungal } \\
\text { medications, } 84(83.17 \%) \text { used } \\
\text { non-invasive ventilator or high- } \\
\text { flow oxygen therapy equipment, } \\
\text { and } 76.24 \% \text { used mechanical } \\
\text { ventilation. invasive. } 7 \text { patients }\end{array}$ & $\begin{array}{l}\text { Critical COVID-19 can cause fatal } \\
\text { respiratory distress syndrome and multiple } \\
\text { organ failure with a high mortality rate. }\end{array}$ \\
\hline
\end{tabular}


results, possible therapy strategies, and test results when her admission, ICU and $48 \mathrm{~h}$ before death were collected and analyzed.

\begin{tabular}{|c|c|c|c|c|c|}
\hline $\begin{array}{l}\text { * Chen M, } \\
\text { et al. }{ }^{18}\end{array}$ & 97 & $\begin{array}{l}\text { Clinical case } \\
\text { study }\end{array}$ & $\begin{array}{l}\text { P patients } \\
\text { with COVID-19 }\end{array}$ & hospitalized & $\begin{array}{l}\text { We analyzed clinical data } \\
\text { from adult patients with } \\
\text { confirmed COVID- } \\
19 \text { admitted to the Fifth } \\
\text { Affiliated Hospital of Sun } \\
\text { Yat-sen University in the } \\
\text { January 17, } 2020 \text { on } \\
\text { March 10, 2020 }\end{array}$ \\
\hline
\end{tabular}

Grasselli G, 1591 Retrospective $\quad$ P patients

with COVID

clinical study with COVID-

\begin{tabular}{|c|c|c|c|c|c|}
\hline $\begin{array}{l}\text { Grasselli G, } \\
\text { et al. }{ }^{19}\end{array}$ & 1591 & $\begin{array}{l}\text { Retrospective } \\
\text { clinical study }\end{array}$ & $\begin{array}{l}\text { P patients } \\
19 \text { disease }\end{array}$ & with COVID- & $\begin{array}{l}\text { Demographic and clinical } \\
\text { data were collected, } \\
\text { including data on clinical } \\
\text { management, respiratory } \\
\text { failure, and patient } \\
\text { mortality. The } \\
\text { coordinating center } \\
\text { recorded the data on an } \\
\text { electronic spreadsheet } \\
\text { during phone calls made } \\
\text { by COVID-19 Lombardy } \\
\text { network staff. }\end{array}$ \\
\hline
\end{tabular}

were treated with ECMO and 8

patients were treated with

CRRT. The median time from

ARDS to invasive mechanical

ventilation was 3.00 days (IQR

$0.00-6.00)$. The duration of

invasive mechanical ventilation

was 5 days (IQR2.00-8.00)

Based on severity, oxygenation L to accurate and timely identification of index, body weight, age, clinical characteristics in serious risks, and underlying diseases, adequate intervention early and adequate could block amount of methylprednisolone the progression of the disease. The applied in severe / critical on- appropriate dose of methylprednisolone can demand COVID-19 patients, effectively prevent invasive mechanical improved blood oxygen and ventilation and reduce the case fatality rate decreased rate utilization of in critically ill patients with COVID-19. invasive mechanical ventilation,

medical and medical case

fatality rate. The most common indications for invasive mechanical ventilation should be strictly controlled in critically ill patients with COVID-19.
In this case series of critically ill patients with laboratory-confirmed COVID-19 data, 1,287 (99\% [95\% CI, 98\% admitted to the ICU, the majority were older $-99 \%$ ]) required respiratory men . A large proportion required support, including $1,150(88 \%$ mechanical ventilation and high levels of 95\% CI， 87\% - $90 \%]$ ]) who PEEP, and ICU mortality was $26 \%$.

received ventilation mechanical and $137(11 \%$ [95\% CI, 9\% $12 \%]$ ) who received noninvasive ventilation. The median end-expiration positive pressure (PEEP) was 14 (IQR, 12-16) cm $\mathrm{H} 2 \mathrm{O}$, and $\mathrm{Fio} 2$ was greater than $50 \%$ in $89 \%$ of patients. Median Pao2 / Fio2 was 160 (IQR, 114220). The median level of PEEP was not different between younger patients $(n=503$ aged $\leq 63$ years) and older patients ( $=514$ aged $\geq 64$ years $)(14[\mathrm{IQR}$ 12-15] vs 14 [IQR, 12-16] cm $\mathrm{H} 2 \mathrm{O}$, respectively; median 
difference, 0 [95\% CI, 0-0]; P =

0.94). The median Fio2 was

lower in younger patients: 60\%

(IQR, $50 \%-80 \%$ ) vs. $70 \%$ (IQR,

$50 \%-80 \%$ ) (median difference,

$-10 \%$ [95\% CI, $-14 \%$ to $6 \%$ ]; P

$=.006$ ), and the median Pao2 /

Fio2 was higher in younger

patients: 163.5 (IQR, 120-230)

versus 156 (IQR, 110-205)

(median difference, 7 [IC $95 \%$,

-8 to 22]; $\mathrm{P}=.02$ ).

\begin{tabular}{|c|c|c|c|c|c|c|c|c|}
\hline $\begin{array}{l}\text { Grein } J \text {, et } \\
\text { al. }^{20}\end{array}$ & 53 & $\begin{array}{l}\text { Clinical } \\
\text { cohort study }\end{array}$ & $\begin{array}{l}\text { P patients } \\
\text { with COVID-19 }\end{array}$ & hospitalized & $\begin{array}{l}\text { P acientes with SARS- } \\
\text { CoV-2 had an oxygen } \\
\text { saturation of } 94 \% \text { or less } \\
\text { while breathing room air } \\
\text { or oxygen } \\
\text { received. Patients } \\
\text { received a 10- } \\
\text { day R emdesivir cycle, } \\
\text { consisting of } 200 \text { mg } \\
\text { given intravenously on } \\
\text { day 1, followed by } 100 \\
\text { mg daily for the } \\
\text { remaining } 9 \text { days of } \\
\text { treatment. }\end{array}$ & 6 weeks & $\begin{array}{l}\text { At the start of the study, } 30 \\
\text { patients (57\%) received } \\
\text { mechanical ventilation and } 4 \\
(8 \%) \text { received extracorporeal } \\
\text { membrane oxygenation. During } \\
\text { a median follow-up of } 18 \text { days, } \\
36 \text { patients }(68 \%) \text { had an } \\
\text { improvement in the oxygen } \\
\text { support class, including } 17 \text { of } 30 \\
\text { patients (57\%) who received } \\
\text { mechanical ventilation who } \\
\text { were extubated. A total of } 25 \\
\text { patients (47\%) were discharged } \\
\text { and } 7 \text { patients (13\%) } \\
\text { died; mortality was } 18 \% \text { of } \\
34) \text { among patients who } \\
\text { received invasive ventilation } \\
\text { and } 5 \%(1 \text { of } 19) \text { among those } \\
\text { who did not receive invasive } \\
\text { ventilation. }\end{array}$ & $\begin{array}{l}64 \% \text { of } \mathrm{R} \text { emdesivir- treated patients were } \\
\text { receiving invasive mechanical ventilation at } \\
\text { baseline, including } 8 \% \text { receiving ECMO, } \\
\text { and mortality in this subgroup was } 18 \% \\
\text { (compared to } 5.3 \% \text { in patients receiving } \\
\text { non-invasive oxygen ). }\end{array}$ \\
\hline $\begin{array}{l}{ }^{*} \text { Herold T, } \\
\text { et al. }{ }^{21}\end{array}$ & 40 & $\begin{array}{l}\text { Clinical case } \\
\text { study }\end{array}$ & $\begin{array}{l}\text { P patients } \\
\text { with COVID-19 }\end{array}$ & hospitalized & $\begin{array}{l}\text { The clinical findings } \\
\text { of patients with } \\
\text { symptomatic infection } \\
\text { proven by COVID-19 } \\
\text { verified by PCR } \\
\text { hospitalized in our } \\
\text { institution from February } \\
29 \text { to March 27, } \\
2020 \text { were analyzed. }\end{array}$ & 4 weeks & $\begin{array}{l}\text { Patients requiring } 13 / 40 \\
\text { mechanical ventilation }(32.5 \%) \\
\text { did not differ in age, } \\
\text { comorbidities, radiological } \\
\text { findings, respiratory rate, or } \\
\text { qSofa score. However, } \\
\text { the elevation of interleukin-6 } \\
\text { (IL-6) was strongly associated } \\
\text { with the need for mechanical } \\
\text { ventilation (p = } 1.2 .10- \\
\text { 5). Furthermore, the maximum } \\
\text { level of IL-6 (cut } 80 \mathrm{pg} / \mathrm{ml}) \text { for } \\
\text { each patient during the disease }\end{array}$ & $\begin{array}{l}\text { The IL-6 is an effective marker that could } \\
\text { predict respiratory failure early with high } \\
\text { accuracy and help physicians to correctly } \\
\text { assign patients at an early stage. }\end{array}$ \\
\hline
\end{tabular}


predicted respiratory failure

with high precision $(\mathrm{p}=1.7 .10$

8 , AUC $=0.98$ ). The risk of

respiratory failure for patients

with IL-6 levels $\geq 80 \mathrm{pg} / \mathrm{ml}$ was

22 times higher compared to

patients with lower levels of IL-

6.

\begin{tabular}{|c|c|c|c|c|}
\hline $\begin{array}{l}\text { Jia-Kui } \\
\text { Sun., et al. }\end{array}$ & 83 & $\begin{array}{l}\text { Retrospective } \\
\text { clinical study }\end{array}$ & $\begin{array}{l}\text { Acute gastrointestinal injury in } \\
\text { critically ill patients } \\
\text { with COVID-19 disease }\end{array}$ & $\begin{array}{l}\text { Demographic data, } \\
\text { laboratory parameters, } \\
\text { LGA grades, clinical } \\
\text { severity, and results were } \\
\text { collected. The primary } \\
\text { end points were LGA } \\
\text { incidence and 28-day } \\
\text { mortality, the secondary } \\
\text { end points were organ } \\
\text { dysfunction and the } \\
\text { incidence of septic shock. }\end{array}$ \\
\hline
\end{tabular}

Patients with worse grades of

LGA had worse clinical

variables, higher incidence of septic shock and mortality at 28

days. Sequential Organ Failure

Assessment (SOFA) scores

(95\% CI, 1,374-2,860; P

$<0.001)$, white blood cell counts

(WBC) (95\% CI, 1,037-1,379; P

$=0.014)$, duration of mechanical

ventilation $(\mathrm{VM}) \quad(95 \% \quad \mathrm{CI}$

$1,020-1,340 ; \mathrm{P}=0.025)$ were

risk factors for the development

of severe grade II LGA.

\begin{tabular}{|c|c|c|c|c|}
\hline $\begin{array}{l}\text { Jiang X, et } \\
\text { al. }^{23}\end{array}$ & 55 & $\begin{array}{l}\text { Retrospective } \\
\text { clinical study }\end{array}$ & $\begin{array}{l}\mathrm{P} \text { acientes critical illness COVID- } \\
19\end{array}$ & $\begin{array}{l}\text { S and collected } \\
\text { epidemiological, } \\
\text { demographic, clinical, } \\
\text { laboratory, imaging, } \\
\text { treatment and patient } \\
\text { outcomes. The follow-up } \\
\text { lasted until April 6, 2020. }\end{array}$ \\
\hline
\end{tabular}

L os patients with severe disease were significantly more often for chloroquine tablets $(37.5 \%$ vs. $2.1 \%, \mathrm{p}=.005)$, antibiotic therapy $(100.0 \%$ versus $44.7 \%$, $\mathrm{p}=.005), \quad$ corticosteroids systemic intravenous $(75.0 \%$ vs $0, \quad \mathrm{p}<0.001)$, intravenous immunoglobulin $\quad(50.0 \%$ vs $2.1 \%, \mathrm{p}<0.001)$, injection of thymosin $(100.0 \%$ vs $25.5 \%$, p $<0.001)$, probiotic tablets $(87.5 \%$ vs $40.4 \%, p=0.037)$ low molecular weight heparin injection (LMWH) $(75.0 \%$ vs $4.3 \%, \mathrm{p}<0.001)$, nasal cannula support $(100.0 \%$ vs $38.3 \%, \mathrm{p}=$ 0.001 ), high flow oxygen nasal cannula support $(37.5 \%$ vs $0, \mathrm{p}=$ $0.002)$ and mechanical ventilation $(87.5 \%$ vs 0 , p

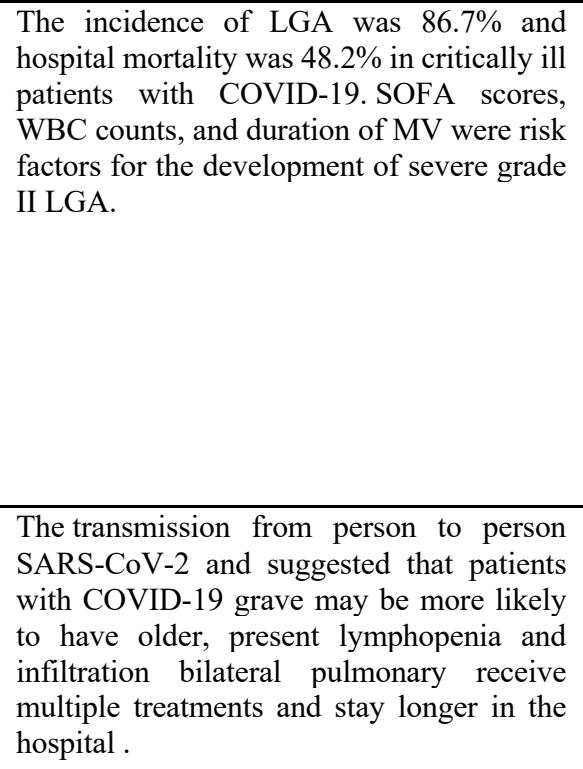
The transmission from person to person SARS-CoV-2 and suggested that patients with COVID-19 grave may be more likely to have older, present lymphopenia and infiltration bilateral pulmonary receive multiple treatments and stay longer in the

hospital .

The incidence of LGA was $86.7 \%$ and ospital mortality was $48.2 \%$ in critically ill ients with COVID-19. SOFA scores, BC counts, and duration of MV were risk factors for the development of severe grade II LGA.

$<0.001$ ). 


\begin{tabular}{|c|c|c|c|c|c|c|c|}
\hline $\begin{array}{ll}\text { Ling } & L \text {, et } \\
\text { al. }^{24} & \end{array}$ & 49 & $\begin{array}{l}\text { Retrospective } \\
\text { clinical study }\end{array}$ & $\begin{array}{l}\mathrm{P} \text { acientes critical illness COVID- } \\
19\end{array}$ & $\begin{array}{l}\text { Clinical data from three } \\
\text { multidisciplinary } \\
\text { intensive care units in } \\
\text { Hong Kong. All critical } \\
\text { adult patients with } \\
\text { confirmed COVID-19 } \\
\text { were admitted to the } \\
\text { ICU in Hong Kong } \\
\text { between January } 22 \text { and } \\
\text { February } 11,2020 .\end{array}$ & 4 weeks & $\begin{array}{l}\text { Six patients }(75 \%) \text { required } \\
\text { mechanical ventilation, six } \\
\text { patients }(75 \%) \text { required } \\
\text { vasopressors, and two }(25 \%) \\
\text { required renal replacement } \\
\text { therapy. None of the patients } \\
\text { required prone ventilation, nitric } \\
\text { oxide, or extracorporeal } \\
\text { membrane oxygenation. The } \\
\text { mean times for shock reversal } \\
\text { and extubation were } 9 \text { and } 11 \\
\text { days, respectively. At } 28 \text { days, } \\
\text { one patient }(12 \%) \text { had died and } \\
\text { the remaining seven ( } 88 \%) \\
\text { survived ICU } \\
\text { discharge. Only one of the } \\
\text { survivors (14\%) still required } \\
\text { oxygen at } 28 \text { days. }\end{array}$ & $\begin{array}{l}\text { Critically ill patients with COVID-19 often } \\
\text { require a moderate duration of mechanical } \\
\text { ventilation and vasopressor support. Most of } \\
\text { these patients recover and survive until ICU } \\
\text { discharge with supportive care using lung } \\
\text { protection ventilation strategies, avoiding } \\
\text { excess fluids, screening and treating } \\
\text { bacterial coinfection and timely intubation. }\end{array}$ \\
\hline $\begin{array}{l}\text { Qi D, } \\
\text { al. }^{25}\end{array}$ & 267 & $\begin{array}{l}\text { Retrospective } \\
\text { clinical study }\end{array}$ & $\begin{array}{l}\text { P patients } \\
\text { with COVID-19 }\end{array}$ & $\begin{array}{l}\text { E n this study multiple } \\
\text { centers, a total of } 267 \\
\text { patients were enrolled } \\
\text { with } \quad \text { COVID-19 } \\
\text { confirmed by RT-PCR in } \\
\text { real time in Chongqing on } \\
\text { January } 19 \text { to February } 16 \\
\text { 2020. }\end{array}$ & 4 weeks & $\begin{array}{l}\text { Invasive mechanical ventilation } \\
\text { in the prone position, non- } \\
\text { invasive mechanical ventilation, } \\
\text { high-flow nasal cannula oxygen } \\
\text { therapy was adopted only in } \\
\text { severe patients with respiratory } \\
\text { failure }(5[10.0 \%], 35[70.0 \%] \text {, } \\
12[24.0 \%]) .\end{array}$ & $\begin{array}{l}\text { Ventilation is the main respiratory support } \\
\text { treatment for critically ill patients, which } \\
\text { should be administered as soon as normal } \\
\text { oxygenation cannot be maintained. }\end{array}$ \\
\hline $\begin{array}{lll}\text { Shi } & \text { S, et } \\
\text { al. }^{26} & \end{array}$ & 416 & $\begin{array}{l}\text { Clinical } \\
\text { cohort study }\end{array}$ & $\begin{array}{l}\text { Cardiac injury in } \\
\text { with COVID-19 disease }\end{array}$ & $\begin{array}{l}\text { Clinical laboratory, } \\
\text { radiological } \\
\text { treatment data were } \\
\text { collected and } \\
\text { analyzed. The results of } \\
\text { patients with and without } \\
\text { cardiac injury were } \\
\text { compared. The } \\
\text { association between } \\
\text { cardiac injury and } \\
\text { mortality was analyzed. }\end{array}$ & - & $\begin{array}{l}\text { Higher proportions of patients } \\
\text { with cardiac injury required non- } \\
\text { invasive mechanical ventilation } \\
(38 \text { of } 82[46.3 \%] \text { versus } 13 \text { of } \\
334[3.9 \%] ; \mathrm{P}<.001) \text { or invasive } \\
\text { mechanical ventilation }(18 \text { of } 82 \\
{[22.0 \%] \text { vs } 14 \text { of } 334 \text { [4.2\%]; } \mathrm{P}} \\
<.001) \text { than those without heart } \\
\text { injury. Complications were } \\
\text { more common in patients with } \\
\text { heart damage than in those } \\
\text { without heart damage and } \\
\text { included acute respiratory } \\
\text { distress syndrome ( } 48 \text { of } 82 \\
{[58.5 \%] \text { vs } 49 \text { of } 334[14.7 \%] ; \mathrm{P}} \\
<.001), \text { acute kidney damage }(7 \\
\text { of } 82[8.5 \%] \text { vs } 1 \text { of } 334[0.3 \%] ; \\
\mathrm{P} \quad<.001), \quad \text { electrolyte } \\
\text { abnormalities }(13 \text { of } 82[15.9 \%]\end{array}$ & $\begin{array}{l}\text { Patients with heart injury had higher } \\
\text { mortality than those without heart injury ( } 42 \\
\text { of } 82[51.2 \%] \text { versus } 15 \text { of } 334[4.5 \%] ; \mathrm{P} \\
<0.001) \text {. In a Cox regression model, patients } \\
\text { versus those without heart injury had an } \\
\text { increased risk of death. }\end{array}$ \\
\hline
\end{tabular}


vs 17 of 334 [5.1\%]; $\mathrm{P}=.003)$

hypoproteinemia ( 11 of 82

[13.4\%] vs 16 of 334 [4.8\%]; P

$=.01)$, and coagulation disorders

(6 of $82[7.3 \%]$ vs 6 of 334

$[1.8 \%] ; \mathrm{P}=.02)$.

\begin{tabular}{llll}
\hline Simonnet & 124 & Study clinical & P patients
\end{tabular}

A, et al. ${ }^{27} \quad$ cohort with COVID-19

hospitalized This

study was analiz or the

relationship between the

clinical features,

including the body mass index (BMI), and the requirement for invasive mechanical ventilation

(V MI ) in 124
consecutive patients admitted to intensive care SARS-CoV-2, in a single French center

Is e xtraj Eron data from

1,099 patients

with SRA 2019-nCoV

laboratory confirmed 552

hospitals in 31 provinces

/ provincial

municipalities until 29

January 2020.
5 weeks

patients $(68.6 \%)$

required IMV. The proportion of

patients requiring

IMV

increased with BMI categories

( $p<0.01$, Chi-square test for

trend), and was higher in

patients with $\mathrm{BMI}>35 \mathrm{~kg} / \mathrm{m} 2$

$(85.7 \%)$. In the multivariate

logistic regression, the need for

IMV was significantly

associated with male sex (p

$<0.05)$ and BMI (p <0.05)

regardless of age, diabetes, and hypertension.

L therapy oxygen, mechanical

ventilation,

intravenous

antibiotics and oseltamivir therapy started in $38.0 \%, 6.1 \%$,

$7.5 \%$ and $35.8 \%$ of patients,

respectively. All of these

therapies were started in significantly higher percentages of severe cases (all P $<0.05)$. Significantly more severe cases received mechanical ventilation (noninvasive: $32.37 \%$ vs. $0 \%, \mathrm{P}$ $<0.001$; invasive: $13.87 \%$ vs $0 \%, \mathrm{P}<0.001$ ) compared to nonsevere cases. Systemic corticosteroids were administered in $18.6 \%$ of cases and more in the severe group than in the non-severe patients $(44.5 \%$ vs. $13.7 \%, p<0.001)$. In addition, extracorporeal

membrane oxygenation was adopted in 5 severe cases, but none in non-severe cases ( $P$
Severe pneumonia was independently

This cohort study showed that obesity is a the severity of SARS-CoV2 disease, which has a greater impact in patients with a BMI $\geq 35 \mathrm{~kg} / \mathrm{m} 2$. care unit, mechanical ventilation, or death in the multivariate competitive risk model. 


\begin{tabular}{|c|c|c|c|c|c|}
\hline $\begin{array}{l}\text { Zheng Y, et } \\
\text { al. }{ }^{29}\end{array}$ & 3.4 & $\begin{array}{l}\text { Retrospective } \\
\text { clinical study }\end{array}$ & $\begin{array}{l}P \text { acientes with } \\
\text { admitted to ICU }\end{array}$ & COVID-19 & $\begin{array}{l}\mathrm{R} \text { is astrea rum data until } \\
5 \text { March } 2020 \text {. The cases } \\
\text { were divided into } \\
\text { cohort patients received } \\
\text { noninvasive ventilation } \\
\text { (INV) and cases requiring } \\
\text { invasive mechanical } \\
\text { ventilation (IMV). The } \\
\text { characteristics between } \\
\text { the two groups were } \\
\text { compared. }\end{array}$ \\
\hline
\end{tabular}

$(3.37 \%)$ and shock $(1.00 \%)$.

The complication rate was

higher

Lymphocytopenia, neutrophilia, and

V MI cases . Lymphocytopenia

and neutrophilia occurred in most cases in both groups on the

day of admission, however,

increased IL-6 and IL-10 occurred in

lymphocyte levels progressively

decreased and more severe

lymphopenia occurred in

the IMV group . Greater

amounts of plasma IL-6 and IL-

10 were found in both groups on

the day of admission, whose

progressive decrease occurred in

cases of NIV compared to cases

of IMV, and the levels were

higher in cases of IMV during

hospitalization.

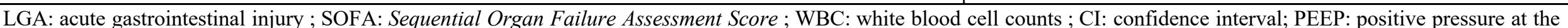

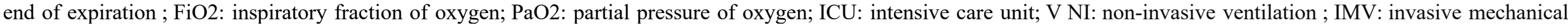

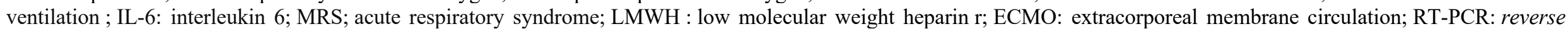
transcription polymerase chain reaction; BMI: body mass index; CRRT : continuous renal replacement therapies

\section{Mechanical ventilation in patients with COVID-19}

Mechanical ventilation is the main respiratory support treatment for critically ill patients, which should be administered as soon as normal oxygenation cannot be maintained ${ }^{25}$. The use of mechanical ventilation in critically ill COVID-19 patients remains a strategy for improving ventilation and mitigating the impact on acute respiratory distress syndrome developed by many patients with coronavirus. Currently, there is little evidence on the needs for MV in patients with coronavirus and the prognosis for improvement. Critically ill patients with COVID-19 often require a moderate duration of mechanical ventilation and vasopressor support ${ }^{24}$. 
medRxiv preprint doi: https://doi.org/10.1101/2020.05.14.20098608; this version posted May 19, 2020. The copyright holder for this preprint (which was not certified by peer review) is the author/funder, who has granted medRxiv a license to display the preprint in perpetuity.

\section{Strategies}

Invasive mechanical ventilation in the prone position ${ }^{15,16,26}$, non-invasive mechanical ventilation ${ }^{15-}$ 17,19,21,23,24,26-29, high flow nasal cannula oxygen therapy ${ }^{15,23,26}$ and extracorporeal membrane oxygenation (ECMO) ${ }^{15,17,20,29}$, are some strategies in critically ill patients with SARS-CoV-2 who develop respiratory failure; as well as the use of neuromuscular blockade, inhaled pulmonary vasodilators and vasopressors ${ }^{16}$.

\section{Mortality}

On the other hand, a high percentage of patients with SARS-CoV-2 who enter the ICU require prolonged mechanical ventilation ${ }^{15,16,17}$ and a higher percentage requires invasive mechanical ventilation ${ }^{15-17,19,20,23,24,25-28}$. Mortality in patients with invasive mechanical ventilation ( $18 \%$ to $33,3 \%)$ seems to be greater compared to non-invasive mechanical ventilation $(\sim 5 \% \text { a } 10 \%)^{15,17}$ and even behaves up to $26 \%{ }^{19}$.

\section{Parameters}

Although there is no current consensus on the parameters of mechanical ventilation in patients with COVID-19, most studies suggest the volume-controlled / assisted ventilatory mode, the use of elevated Fio 2 from day 1 of mechanical ventilation, among $60 \%$ and $90 \%{ }^{16,19}$, although the mean in the different studies was Fio2 $50 \%{ }^{19}$, a pulmonary compliance to $29-37 \mathrm{ml}$ for $\mathrm{cm}$ to water $^{16}$, positive pressure at the end of expiration (PEEP) of 14 (IQR, 12-16) $\mathrm{cm} \mathrm{H2O}$, plateau pressure of less than $30 \mathrm{ml} \mathrm{H2o}$, a driving pressure (the difference between the plateau pressure to the PEEP) of 12-14 cm of water ${ }^{16,19}$ and a pressure plateau of $22-25 \mathrm{~cm}$ of water ${ }^{1616,19}$ are the guidelines recommended by the evidence collected.

\section{Comorbidities and injuries}

Patients with cardiac injury and COVID-19 require more mechanical ventilation support than those without cardiac injury ${ }^{26} ; 46.3 \%$ non-invasive and $22 \%$ invasive mechanical ventilation ${ }^{26}$. On the other hand, higher values of body mass index (IMC> $35 \mathrm{~kg} / \mathrm{m} 2$ ) are associated with higher invasive mechanical ventilation requirements ${ }^{27}$. Similarly, higher levels of systemic blood pressure are associated with higher demand for MV and higher mortality ${ }^{19,22,27}$. 
medRxiv preprint doi: https://doi.org/10.1101/2020.05.14.20098608; this version posted May 19, 2020. The copyright holder for this preprint (which was not certified by peer review) is the author/funder, who has granted medRxiv a license to display the preprint in perpetuity. It is made available under a CC-BY-NC-ND 4.0 International license .

Furthermore, the elevation of interleukin-6 (IL-6) is strongly associated with the need for mechanical ventilation. Furthermore, the maximum level of IL-6 (cut $80 \mathrm{pg} / \mathrm{ml}$ ) for each patient during the disease predicts respiratory failure with high precision. The risk of respiratory failure for patients with IL-6 levels $\geq 80 \mathrm{pg} / \mathrm{ml}$ is 22 times higher compared to patients whose levels of IL-6 are lower. Also, the incidence of acute gastrointestinal injury (LGA) in critically ill patients with COVID-19 undergoing prolonged MV is frequent $(86.7 \%)^{21}$.

Lymphocytopenia and neutrophilia occur in most cases, however, lymphocyte levels progressively decrease and lymphopenia occurs, which is more severe in patients with IMV ${ }^{29}$. Likewise, the rate of patients undergoing continuous renal replacement therapy for multiple organ failure and kidney injury in patients with SARS-CoV-2 is high ${ }^{17,24,26}$. Furthermore, critical COVID-19 can cause fatal respiratory distress syndrome and multiple organ failure with a high mortality rate 17 and very frequently pneumonia (79.1\%), followed by ARDS (3.3\%) and shock $(1.0 \%)^{28}$.

\section{Other strategies}

The use of methylprednisolone applied in critically ill COVID-19 patients appears to improve blood oxygen, reduce the rate of use of IMV, and the mortality rate ${ }^{18}$.

\section{DISCUSSION}

This systematic review highlights the needs for basic and advanced respiratory support in patients with SARS-CoV-2. The respiratory care in COVID-19 described by Meza, C. et al. $(2020)^{30}$ seeks to generate lung protection strategies by decreasing tidal volumes, plateau pressure, respiratory rates, driving pressure values and prone ventilation, as well as implementing high PEEP values, which have shown improvement in hypoxemia and survival in patients with acute respiratory distress syndrome, the same characteristics described in this article based on the needs for protective mechanical ventilation in patients with coronavirus and with a prognosis for improvement.

On the other hand, other statements ${ }^{31}$ mention that mechanical ventilation is capable of producing and aggravating lung damage by the administration of supplemental oxygen in inadequate amounts, highlighting that the effects of hyperoxia in the lungs can lead to the formation of alveolar hyaline membrane, edema, hyperplasia, proliferation of type II pneumocytes, destruction of type I pneumocytes, interstitial fibrosis and pulmonary vascular remodeling, data that resemble those 
medRxiv preprint doi: https://doi.org/10.1101/2020.05.14.20098608; this version posted May 19, 2020. The copyright holder for this preprint (which was not certified by peer review) is the author/funder, who has granted medRxiv a license to display the preprint in perpetuity. It is made available under a CC-BY-NC-ND 4.0 International license .

proposed in the present investigation, associating that the inadequate dosage of oxygen according to the patient's clinical conditions would result counterproductive in its evolution.

Likewise, Vidal, F. \& Calderón, V. (2012) ${ }^{32}$ affirm that mechanical ventilation in acute respiratory distress syndrome not only involves respiratory disorders but also supposes an elevation of alveolar and transpulmonary pressure, conditioning a significant alteration and overload. for the function of the right ventricle that can fail giving rise to the clinical picture of acute pulmonary cor, it is for this reason that the importance of continuous monitoring of pulmonary and hemodynamic mechanics is highlighted when considering ventilatory strategies; likewise, as mentioned by Gattinoni L. et al. (2020) ${ }^{33}$ referring to the phenotypes of SARS-CoV-2 associated pneumonia. In this way, it is reported in a study ${ }^{34}$ that the prone position has a great impact on cardiopulmonary physiology, being a useful and accessible maneuver for most intensive care units, and the findings are also mentioned in the present investigation. relevant of this technique on terms of survival in patients with relatively severe ARDS $(\mathrm{PaO} 2 / \mathrm{FiO} 2 \leq 150 \mathrm{mmHg})$ highlighting that it is necessary to reevaluate the levels of PEEP once the maneuver has been performed, adjusting to the particularities of each clinical situation.

In another study ${ }^{35}$, they mention that the use of muscle relaxants in the hypoxemic patient seeks to improve patient-ventilator synchrony, resulting in conflict with the development of myopathy as well as reducing the benefits of spontaneous breathing, as it was also shown that muscle relaxants, in patients with ARDS criteria treated under deep sedation showed an improvement in thoracic compliance and a decrease in $\mathrm{O} 2$ consumption.

That said, the use of non-invasive mechanical ventilation is questioned due to the findings found for its use in patients with ARDS as described by Franca, A. et al. (2014) ${ }^{36}$ showing a trend of higher failure and mortality in hypoxemic respiratory failure, also emphasizes that values of respiratory rate $>30 \mathrm{rpm}$ in the first hour of NIV are associated with failure in hypoxemic and hypercapnic respiratory failure accompanied by a greater number of infectious complications. Therefore, its use is limited to the different respiratory situations of the patient in which its placement is valued by the respiratory conditions as well as its hemodynamic stability described in the present investigation.

Consequently, Cristancho, W. (2020) $)^{37}$ mentions the use of extracorporeal membrane oxygenation (ECMO) as an alternative to respiratory care, stating that its early use did not significantly improve mortality in patients with severe ARDS, however when used as a modality of rescue could help 
medRxiv preprint doi: https://doi.org/10.1101/2020.05.14.20098608; this version posted May 19, 2020. The copyright holder for this preprint (which was not certified by peer review) is the author/funder, who has granted medRxiv a license to display the preprint in perpetuity. It is made available under a CC-BY-NC-ND 4.0 International license .

improve survival in patients with acute respiratory syndrome. And what has been said in this research, added to the corroborative evidence that we find from our findings, is to highlight that the actions in intensive care are fundamental for the survival of patients whose consequences have already been mentioned, together with prolonged periods of immobilization and bed rest, among which are those mentioned by the Pan American Health Organization ${ }^{38}$ : Impaired lung function; physical deconditioning and muscle weakness; cofusional symptoms and other cognitive deficiencies; dysphagia and difficulties to communicate; mental health disorders and need for psychosocial support. Therefore, the need for rehabilitation professionals who play an important role in ICUs by facilitating early discharge is considered, which is especially important in a context of scarcity of hospital beds. Likewise, to prevent and intervene in sequelae associated with severe COVID-19. For this reason, rehabilitation professionals should be assigned to ICUs, hospital wards, transition facilities and the community.

However, it should be noted that the limitations of this study refer to the limited scientific evidence on the use of mechanical ventilation in patients with SARS-CoV-2, however, different authors suggest, like this review, that the Invasive mechanical ventilation is associated with a worse prognosis and a higher percentage of mortality when not used correctly and with academic grounds. Similarly, the importance of very good early advanced ventilatory support is highlighted, since it can avoid the use of IMV in patients with COVID-1939-43.

\section{CONCLUSIONS}

All SARS-CoV-2 patients require respiratory support and a very high rate requires mechanical ventilation. IL-6 is shown as a possible marker of respiratory failure and a worse prognosis, like that of patients with obesity. In addition, the use of prone position, neuromuscular blockade, pulmonary vasodilators, ECMO, and mechanical ventilation based on the clinical conditions and needs of the patient with COVID-19 are strategies that could benefit patients entering intensive therapy for COVID-19. Likewise, it is highlighted that the use of methylprednisolone seems to reduce mortality and hospital stay. 
medRxiv preprint doi: https://doi.org/10.1101/2020.05.14.20098608; this version posted May 19, 2020. The copyright holder for this preprint (which was not certified by peer review) is the author/funder, who has granted medRxiv a license to display the preprint in perpetuity. It is made available under a CC-BY-NC-ND 4.0 International license .

\section{REFERENCES}

1. World Health Organization. (10 May 2020). Coronavirus disease 2019 (COVID-19): Situation report - 111. [10 May 2020]. Available in: https://www.who.int/docs/defaultsource/coronaviruse/situation-reports/20200510covid-19-sitrep-111.pdf?sfvrsn=1896976f_2

2. European Centre for Disease Prevention and Control. (10 May 2020). COVID-19 situation update worldwide, as of 10 May 2020. [10 May 2020]. Available in: https://www.ecdc.europa.eu/en/geographical-distribution-2019-ncov-cases

3. Li, H., Liu, S. M., et al. (2020). Coronavirus disease 2019 (COVID-19): current status and future perspectives. International journal of antimicrobial agents, 105951. Advance online publication. https://doi.org/10.1016/j.ijantimicag.2020.105951

4. Cascella, M., Rajnik, M., Cuomo, A., et al. (2020). Features, Evaluation and Treatment Coronavirus (COVID-19) [2020 Apr 6]. In: StatPearls [Internet]. Treasure Island (FL): StatPearls Publishing. Disponible en: https://www.ncbi.nlm.nih.gov/books/NBK554776/

5. Yang, P., \& Wang, X. (2020). COVID-19: a new challenge for human beings. Cellular and Molecular Immunology, 1-3. Advance online publication. https://doi.org/10.1038/s41423$\underline{020-0407-X}$

6. Yuki, K., Fujiogi, M., \& Koutsogiannaki, S. (2020). COVID-19 pathophysiology: A review. Clinical immunology (Orlando, Fla.), 215, 108427. Advance online publication. https://doi.org/10.1016/j.clim.2020.108427

7. Kakodkar, P., Kaka, N., \& Baig, M. N. (2020). A Comprehensive Literature Review on the Clinical Presentation, and Management of the Pandemic Coronavirus Disease 2019 (COVID19). Cureus, 12(4), e7560. https://doi.org/10.7759/cureus. 7560

8. Möhlenkamp, S., \& Thiele, H. (2020). Ventilation of COVID-19 patients in intensive care units. Beatmung von COVID-19-Patienten auf Intensivstationen. Herz, 1-3. Advance online publication. https://doi.org/10.1007/s00059-020-04923-1

9. McEnery, T., Gough, C., \& Costello, R. W. (2020). COVID-19: Respiratory support outside the intensive care unit. The Lancet. Respiratory medicine, S2213-2600(20)30176-4. Advance online publication. https://doi.org/10.1016/S2213-2600(20)30176-4

10. Intensive Care National Audit and Research Centre. (27 Mar 2020). ICNARC report on COVID-19 in critical care. [10 May 2020]. Available in: 
medRxiv preprint doi: https://doi.org/10.1101/2020.05.14.20098608; this version posted May 19, 2020. The copyright holder for this preprint (which was not certified by peer review) is the author/funder, who has granted medRxiv a license to display the preprint in perpetuity. It is made available under a CC-BY-NC-ND 4.0 International license .

file://C:/Users/J.\%20Camilo\%20Quintero/Downloads/ICNARC\%20COVID19\%20report\%202020-03-27.pdf.pdf

11. Asociación Médica Mundial. (21 mar 2017). Declaración de Helsinki de la AMM-Principios éticos para las investigaciones médicas en seres humanos. 64 Asamblea General, Fortaleza, Brasil, octubre 2013. 1-5. Available in: https://www.wma.net/es/policies-post/declaracion-dehelsinki-de-la-amm-principios-eticos-para-las-investigaciones-medicas-en-seres-humanos/

12. Liberati, A., Altman, D., Tetzlaff, J, et al. The PRISMA statement for reporting systematic reviews and meta-analyses of studies that evaluate healthcare interventions: explanation and elaboration. BMJ. 2009; 339: b2700.

13. PRISMA. Transparent Reporting of Systematic Reviews And Meta-Analyses. PRISMA Flow Diagram. [10 May 2020]. Available in: $\underline{\text { http://prisma- }}$ statement.org/PRISMAStatement/FlowDiagram

14. PRISMA. Transparent Reporting of Systematic Reviews And Meta-Analyses. PRISMA Checklist. [10 May 2020]. Available in: statement.org/prismastatement/Checklist.aspx

15. Barrasa, H., Rello, J., Tejada, S., et al. (2020). SARS-Cov-2 in Spanish Intensive Care: Early Experience with 15-day Survival In Vitoria. Anaesthesia, Critical Care \& Pain Medicine. https://doi.org/10.1016/j.accpm.2020.04.001*

16. Bhatraju, P. K., Ghassemieh, B. J., Nichols, M., et al. (2020). Covid-19 in Critically Ill Patients in the Seattle Region-Case Series. The New England Journal of Medicine. https://doi.org/10.1056/NEJMoa200450. *

17. Chen, Ji., Fan, H., Zhang, L., et al. (2020). Retrospective Analysis of Clinical Features in 101 Death Cases with COVID-19. MedRxiv, 2020.03.09.20033068. https://doi.org/10.1101/2020.03.09.20033068*

18. Chen, M., Tu, C., Tan, C., et al. (2020). Key to successful treatment of COVID-19: Accurate identification of severe risks and early intervention of disease progression. MedRxiv, 2020.04.06.20054890. https://doi.org/10.1101/2020.04.06.20054890*

19. Grasselli, G., Zangrillo, A., Zanella, A., et al. (2020). Baseline Characteristics and Outcomes of 1591 Patients Infected With SARS-CoV-2 Admitted to ICUs of the Lombardy Region, Italy. JAMA. https://doi.org/10.1001/jama.2020.5394* 
medRxiv preprint doi: https://doi.org/10.1101/2020.05.14.20098608; this version posted May 19, 2020. The copyright holder for this preprint (which was not certified by peer review) is the author/funder, who has granted medRxiv a license to display the preprint in perpetuity. It is made available under a CC-BY-NC-ND 4.0 International license .

20. Grein, J., Ohmagari, N., Shin, D., et al. (2020). Compassionate Use of Remdesivir for Patients with Severe Covid-19. The New England Journal of Medicine. https://doi.org/10.1056/NEJMoa2007016*

21. Herold, T., Jurinovic, V., Arnreich, C., et al. (2020). Level of IL-6 predicts respiratory failure in hospitalized symptomatic COVID-19 patients. MedRxiv, 2020.04.01.20047381. https://doi.org/10.1101/2020.04.01.20047381*

22. Jia-Kui, S. (2020). Acute gastrointestinal injury in critically ill patients with coronavirus disease 2019 in Wuhan, China. MedRxiv, 2020.03.25.20043570. https://doi.org/10.1101/2020.03.25.20043570*

23. Jiang, X., Tao, J., Wu, H., et al. (2020). Clinical features and management of severe COVID19: A retrospective study in Wuxi, Jiangsu Province, China. MedRxiv, 2020.04.10.20060335. https://doi.org/10.1101/2020.04.10.20060335*

24. Ling, L., So, C., Shum, H. P., et al. (2020). Critically ill patients with COVID-19 in Hong Kong: A multicentre retrospective observational cohort study. Critical Care and Resuscitation: Journal of the Australasian Academy of Critical Care Medicine. *

25. Qi, D., Yan, X., Tang, X., et al. (2020). Epidemiological and clinical features of 2019-nCoV acute respiratory disease cases in Chongqing municipality, China: A retrospective, descriptive, $\begin{array}{lll}\text { multiple-center } \quad \text { study. } & \text { MedRxiv, }\end{array}$ https://doi.org/10.1101/2020.03.01.20029397*

26. Shi, S., Qin, M., Shen, B., et al. (2020). Association of Cardiac Injury With Mortality in Hospitalized Patients With COVID-19 in Wuhan, China. JAMA Cardiology. https://doi.org/10.1001/jamacardio.2020.0950*

27. Simonnet, A., Chetboun, M., Poissy, J., et al. (2020). High prevalence of obesity in severe acute respiratory syndrome coronavirus-2 (SARS-CoV-2) requiring invasive mechanical ventilation. Obesity (Silver Spring, Md.). https://doi.org/10.1002/oby.22831

28. Wei-jie, G., Ni, Z., Hu, Y., Liang, W., et al. (2020). Clinical characteristics of 2019 novel coronavirus infection in China. MedRxiv, 2020.02.06.20020974. https://doi.org/10.1101/2020.02.06.20020974*

29. Zheng, Y., Sun, L., Xu, M., et al. (2020). Clinical characteristics of 34 COVID-19 patients admitted to ICU in Hangzhou, China. MedRxiv, 2020.04.12.20062604. https://doi.org/10.1101/2020.04.12.20062604* 
medRxiv preprint doi: https://doi.org/10.1101/2020.05.14.20098608; this version posted May 19, 2020. The copyright holder for this preprint (which was not certified by peer review) is the author/funder, who has granted medRxiv a license to display the preprint in perpetuity. It is made available under a CC-BY-NC-ND 4.0 International license .

30. Meza C, López L, Guerrero H, et al. (2020). Respiratory care in Covid-19. Acta Colombiana de Cuidado Intensivo. 10.1016-j.acci.2020.04.001

31. Seiberlich E, Santana J, Cháves A, et al. (2011). Ventilación Mecánica Protectora. Revista Brasileña de anestesiología. 61 (5) 361-365.

32. Vidal F, Calderón V. (2012). Acute Respiratory Distress Syndrome, mechanical ventilation and right ventricular function. Medicina Intensiva. 36(2) 138-142. 10.1097/MCC.0b013e328342722b.

33. Gattinoni, L., Chiumello, D., Caironi, P. et al. (2020). COVID-19 pneumonia: different respiratory treatments for different phenotypes?. Intensive Care Med. https://doi.org/10.1007/s00134-020-06033-2

34. Setten M, Plotnikow G, Accoce M. (2016). Prone position in patients with acute respiratory distress syndrome. Revista Brasileña de Terapia Intensiva. 28 (4) 452-462

35. Martín M, Fernández F. (2013). Estrategias frente a la hipoxemia refractaria en el síndrome de dificultad respiratoria. Medicina Intensiva. 37(6) 423-430. 10.1016/j.medin.2012.12.007

36. Franca A, Ignacio C, Soledad O, et al. (2014). Asistencia Ventilatoria no Invasiva en el tratamiento inicial de la insuficiencia respiratoria aguda. Revista médica del Uruguay. 30(3) 168-178.

37. Cristancho W. (2020) Ventilación Mecánica en Covid-19. Ciencias de la Salud Manual Moderno. 2(1) 16-17. Disponible online en: https://www.manualmoderno.com/blog/post/ventilacion-mecanica-en-covid-19.-unaaproximacion-practica/

38. Pan American Health Organization. (2020). Consideraciones relativas a la rehabilitacion durante el brote de COVID-19. Available in: https://iris.paho.org/handle/10665.2/52104

39. Möhlenkamp, S., \& Thiele, H. (2020). Ventilation of COVID-19 patients in intensive care units. Beatmung von COVID-19-Patienten auf Intensivstationen. Herz, 1-3. Advance online publication. https://doi.org/10.1007/s00059-020-04923-1

40. Arulkumaran, N., Brealey, D., Howell, D., \& Singer, M. (2020). Use of non-invasive ventilation for patients with COVID-19: a cause for concern?. The Lancet. Respiratory medicine, S2213-2600(20)30181-8. Advance online publication. https://doi.org/10.1016/S2213-2600(20)30181-8 
medRxiv preprint doi: https://doi.org/10.1101/2020.05.14.20098608; this version posted May 19, 2020. The copyright holder for this preprint

(which was not certified by peer review) is the author/funder, who has granted medRxiv a license to display the preprint in perpetuity.

It is made available under a CC-BY-NC-ND 4.0 International license .

41. McEnery, T., Gough, C., \& Costello, R. W. (2020). COVID-19: Respiratory support outside the intensive care unit. The Lancet. Respiratory medicine, S2213-2600(20)30176-4. Advance online publication. https://doi.org/10.1016/S2213-2600(20)30176-4

42. Hanidziar, D. y Bittner, EA (2020). Sedación de pacientes con COVID-19 ventilados mecánicamente: desafíos y consideraciones especiales. Anestesia y Analgesia, 10.1213 / ANE.0000000000004887. https://doi.org/10.1213/ANE.0000000000004887

43. Takhar, A., Walker, A., Tricklebank, S., Wyncoll, D., Hart, N., Jacob, T., Arora, A., Skilbeck, C., Simo, R., \& Surda, P. (2020). Recommendation of a practical guideline for safe tracheostomy during the COVID-19 pandemic. European archives of oto-rhino-laryngology : official journal of the European Federation of Oto-Rhino-Laryngological Societies (EUFOS) : affiliated with the German Society for Oto-Rhino-Laryngology - Head and Neck Surgery, 112. Advance online publication. https://doi.org/10.1007/s00405-020-05993-X 
medRxiv preprint doi: https://doi.org/10.1101/2020.05.14.20098608; this version posted May 19, 2020. The copyright holder for this preprint (which was not certified by peer review) is the author/funder, who has granted medRxiv a license to display the preprint in perpetuity.

\author{
It is made available under a CC-BY-NC-ND 4.0 International license
}

